\title{
The "Africanization" of an African Diaspora Household: Toyin Falola and the Idea of Diasporic Home-Making
}

\author{
Babatunde Jaiyeoba \\ Department of Architecture \\ Obafemi Awolowo University \\ Ile-Ife \\ Nigeria \\ tundejaiyeoba@yahoo.co.uk; ebjaiye@oauife.edu.ng \\ Adeshina Afolayan \\ Department of Philosophy \\ University of Ibadan \\ Nigeria \\ adeshinaafolayan@gmail.com
}

\begin{abstract}
This essay is an exercise in the interrogation of cultural globalization, and how the idea of transnationalism generates identity responses. The authors used the concept of home-making to examine how Toyin Falola deployed an aesthetic sensibility of African art as ideological dynamics for the personalization of his home situated in a suburb in Austin, Texas. The Africanization agenda that the Falola house operationalized points at the critical role that interior decoration can play in African diaspora homes. The project is crucial because it undermines the homogenizing reach of globalization that dislocates the sense of identity of an average African transnational migrant. In the Falola home, we confront an assemblage of aesthetic consciousness, dynamics of Africanity, and identity construction.
\end{abstract}




\section{Introduction: Toyin Falola and Diasporic Home-Making}

This essay attempts to provide an answer to Arjun Appadurai's question by examining the artistic Africanization of an African diaspora house, using Toyin Falola's house at Austin, Texas as a critical illustration. Appadurai asks: "How can something local be produced within a process of globalization so solidly committed to the celebration of cosmopolitanism?" (1996: 4). This question speaks to the complexities of globalization and its conceptual capacity to produce heated discourses around homogenization and fragmentation, nationalism and cosmopolitanism, identity and hybridity, and even modernity and civilization. According to Guillen, globalization could be significantly regarded as "an ideology with multiple meanings and lineages" defined around five questions: Is globalization really happening? Does it produce convergence? Does it undermine the authority of nation-states? Is globality different from modernity? Is a global culture in the making? (2001: 236, 242-243). Even Brexit is ideologically tied in with the many complexities of globalization.

Globalization is defined by a trade, consumptive and diaspora dynamics which speaks to an identity problematic for those caught in the homemetropole migration that began with the slave trade and has metamorphosed into an immigration pattern that drains Africa of its human capital. In the form of exiles and migrants. According to Binsbergen, globalization has defined individuals and cultures not as producers but essentially as global consumers of "manufactured goods, information, ideas and images that the dramatic increase in means of communication (both physical and electronic) in the course of the second half of this century has made available" (1994: 4). Globalization intrudes into identity matrix in an interesting manner that undermines our intuitive suspicion of fragmentation in the service of homogenization and uniformity. On the contrary, localities tap into globalization in ways that transform our understanding of "culture". Thus, "Rather than thinking of culture as roots, as peoples belonging to particular places and traditions and practices, we need to think of culture as routes, as the movements of peoples, goods, ideas from place to place" (Wise, 2008: 27).

In what sense is Falola's house an embodiment of a struggle for identity? In what sense, that is, does its "Africanization" a local production reacting against "a process of globalization," according to Appadurai? How does the artistic decoration of a diaspora house reflect the idea of culture as routes, the interconnections that traverse multiple spaces and temporalities across the globe? Falola's house serves as a juncture; the focal point where meaning, territory, creativity, tradition, identity and culture converge. Wise calls this "home-making"-the "process of shaping spaces, uses, and meanings to create 
and maintain identity, to create and maintain a space of comfort" (2008: 18). In what sense, therefore, is Falola's "home-making" a search for origin or an attempt to exploit globalization in a manner that "lend new strength to local idioms, so as to impose on the global scene the original version in place of its translation and adaptation," according to Appadurai (1996: 6)?

\section{Transnational Migrants and Identity Construction}

Globalization is known to have reduced the world into a global village with the potential of unifying thoughts, ideas and culture. Concurrently, globalization consolidates homogenization and differentiates identity. "Contemporary globalization with its time-space compression and pluralization of life-worlds has again impacted the social, cultural and subjective to foster transformations of identity" (Langman, 2003). This is the case with the concept of the "transnational" migrants (Glick-Schiller, Basch \& Blanc, 1995; Glick-Schiller, 1999) who travel from one country to another for different purposes, but mostly in search of a better life. Transnational migrants, while embedding themselves into their new locations, continue to maintain contact with the home society, culture and language (Skandrani, Taieb \& Moro, 2012). In an intercultural psychology approach, Berry and San (1997) differentiate among four acculturation strategies adopted by transnational migrants in identity construction. The assimilation strategy ensures that the migrant may integrate into the new location in a series of cultural processes that undermine the migrant's original cultural identity. The other extreme of the accommodation strategy is separation. Here, the individual retains the original cultural identity and assiduously refuse to be integrated. The marginalization strategy involves the loss of ties with both the original home culture and the culture of the new location. The individual that maintains strong ties with both the original culture and the new settlement culture adopts an integration strategy. The Toyin Falola experience adopts an integration strategy of identity construction. Transnational identity strategies integrate stories and struggles about the nature of the self and all the possibilities attached to what the self can be, especially in contexts other than its own. According to Wise, they are stories about the struggles for identities,

...to find out for oneself who one is, and to be that in the face of what everyone else seems to think you should be. These are stories of a struggle with the idea that one can only be one thing or the other; that there is a choice, and that one can choose to be authentic this or authentic that, or not. These are stories which are not new, but I feel are growing in frequency worldwide. These are stories of people in a particular place, at a particular time, who are dealing with the legacies of other places and other times. 
We could state that these are stories of globalization, and they are, though they seem much more personal than the issues usually addressed around that trendy term. But most of all these are stories of culture, of the realm of meanings, traditions, and experiences; of the frameworks through which people make sense of their lives and how parents, friends, and people on the street seek to shape that framework. These are stories of culture in a global time $(2008,2)$.

While globalization and its flows have often been analyzed with regard to their influence on sociocultural and political issues at the macro-level of analysis, there are several micro-levels at which global processes affect the construction of identity of transnational migrants. Apart from the major players on the global scene, from nation-states to multinational organizations, globalization is also about everyday engagements with self-construction and personal negotiations with identity matters. These engagements and negotiations force on the transnationals a dilemma of cultural and identity choices; of the pains and perils of liminal existence.

\section{The Aesthetics of Personalized Home-Making}

The struggle for identity in transnational dynamics requires spatial reconfiguration of meanings. And one of the best places to achieve this is the understanding we bring to the idea of the home as the space for rethinking identity. The thought of home, especially for migrants, represents a nostalgic juncture at which meaning, tradition and experience coalesce into the attempt to (re)construct identity. The idea of home and the process of home-making, according to Wise, derives from a sense of cultural identification: "We draw on cultural meanings, habits, practices, and objects in making our spaces of comfort. In this notion of home, we can see the intersection of our discussions of culture, habitus, identity, territory, power, and popular culture" (ibid, 19). Wise uses the concept of an assemblage to make the point about the coherence of meaning that a home represents:

An assemblage is a heterogeneous collection of people and things. These collections of things are both structured (by families, societies, cultures, and institutions) and contingent (relying on the availability of resources, individual intention, and chance). But the assemblage is not just a person and his or her things but the relation among all these things, the qualities of these things, their meanings and ideas, habits, rhythms (ibid.).

The idea of the home as an assemblage also helps us to come to terms with the idea of the self as what inhabits the home and personalizes it for identity 
construction. William James furnishes us with such an understanding of the self. For James,

a man's Self is the sum total of all that he can call his, not only his body and his psychic powers, but his clothes and his house, his wife and children, his ancestors and friends, his reputation and works, his lands and horses, and yacht and bank-account. All these things give him the same emotions. If they wax and prosper, he feels triumphant; if they dwindle and die away, he feels cast down, not necessarily in the same degree for each thing, but in much the same way for all $(1981,292-293)$.

Thus, the self is that which possesses things. Material possession is a means of self-expression and communicating to one self and to other people a commitment to an identity (Weigert, Teitge \& Teitge, 1986). When these material possessions are put together in a particular way that makes coherent sense, it facilitates the process of home-making defined around specific meanings. This personalization of space, for Fidzani and Read (2014), allows for an exploration of alternative selves and possible identities. For instance, the work of Gosling et al reveals that personal living space iterates the many dimensions of the home, especially as a space which affords "privacy, refuge, security, continuity, a medium for personalization and self-representation, and a venue for regulated social interactions" $(2005,703)$. One useful means of achieving this personalization is through interior decoration.

Decorations of various forms are used to improve the aesthetics of interior and exterior of spaces and buildings. Decorations also have different value attributes to the decorator beyond prices or real cost. In fact, some like artworks are treasured possessions. In a study of 14- to 18-year-old high school American adolescents, Krampter (1995) defined a multiplicity of meanings that treasured possessions may have. These include utilitarian, social and enjoyment meanings. More purposeful meanings include memory meaning for places and people; intrinsic quality meaning of uniqueness and irreplaceability and self-meaning which is representative of the owner. Treasured possessions including artworks when used for internal decoration give purposeful meanings to the home signifying personalization. Fidzani and Read (2014) explored which design features, decorative items and personal items in adolescent bedrooms are used to express identity. And personalization is the strategy that enabled them promote the exploration and feedback of who they were and/or wanted to be, and supported personal goals and interests. Castells (2000) argues that identities in network society may conform or oppose the status quo or articulate new projects. 


\section{Toyin Falola and the Personalization of Diasporic Identity}

Toyin Falola, the Jacob and Frances Sanger Mossiker Chair in the Humanities at the University of Texas at Austin, the United States, represents a conscious transnational migrant whose cultural and identity experiences reveals a lot about the dynamics of identity construction. Falola's transnational cultural experience is mediated by an active consciousness of Africa and its diaspora, the racial and cultural dynamics of the United States, the Africana imperatives in scholarship, as well as the urgency of unraveling an Africanization agenda that will serve as the basis for putting Africa at the center of the self and the continent. And there seems no better way to commence such an agenda than through a personalization project that transform his home into an active and aesthetic discourse on an Africanized home-making and identity construction. The Falola house is essentially a transnationalized house that relocates an African aesthetics ambience into the heart of the diaspora. Located in one of the super suburbs about 20 miles north of the Austin downtown, it provides a coherent sense of order and meaning that represents the identity consciousness of its owner. The house is the same two-level family building in an Ebenezer Howard garden type environment that is demarcated only with gardens (Fig. 1). The community is decidedly the best of Western sustainable planning concept for which residential neighborhoods in Austin, Texas is known for. In fact, the buildings around are of the same design and typology but for slight variations.

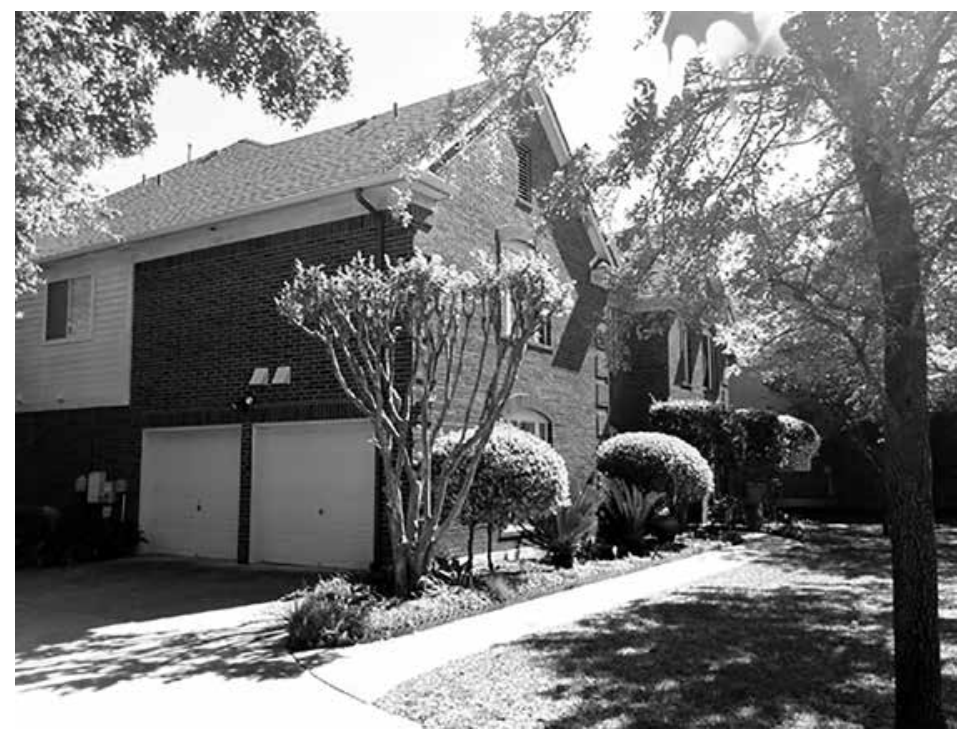

Figure 1: Exterior view of the House 
Austin represents the template of a rapidly growing city. It has grown from being the $42^{\text {nd }}$ largest city in USA in 1980, and the $11^{\text {th }}$ largest in 2010 to being described as the "nation's capital for population growth" (US Census, 2014; Long, 2016). The reputation derives from Austin's stunning economic growth, reflected in its achievement of being one of the fastest growing economies in the United States for four years in a row (Carlyle, 2014). The capacity to blend economic growth and rapid urbanization with a deep understanding of the dynamics of the environment and its sustainability has led to the trumpeting of the "Austin model" of urban sustainability (Long, 2016). The Falola house is located in one of the many well-planned housing communities in the Austin suburb with repetitive housing units sometimes with varied colored brick external finish.

From the outside the house appears the same as any other in the area until the front door is opened. Right within, one steps into an interior that, in all likelihood, still reflects the architectural shape of the other houses in the region, but that has been personalized in accordance with an ideological initiative instigated by Afrocentrism (Fig. 2). The persona of Toyin Falola is an embodiment of an African aesthetic sensibility that reflects in how he dresses and the arts he cherishes. The dynamics of his transnational existence is grounded in an Africanizing project that is programmatized not only in the number of the books on African themes and subject matter, or the number of African scholars already mentored, but antecedently interiorized in the idea of home-making that transformed the Falola home into an assemblage of the aesthetic material possession that drives the mental and intellectual challenge of making a home in a foreign land.

This is a dimension of Afrocentrism-the inscription of the home of an Afrocentric scholar with the fundamental tenets of the Afrocentric ideology - that has not been factored into the dynamics of Afrocentrism. One of the internal tensions that troubles Afrocentrism has to do with the charge of ideological complicity. Afrocentric scholars rail against linguistic imperialism, for instance, through either the English or the French language. And they pursue their ideological radicalism in the finest of Western attires. While Falola could be challenged on the tension of pursuing an Afrocentric worldview from an diasporic point rather than the continental homeland, his response would likely be the importation of the homeland into the diaspora. In his very self, as well as the idea of home-making, Falola literally embodies the Africa he loves and preaches.

Once one steps inside the house, one arrives at a gallery where Falola curates African and Nigerian arts. The living spaces, bedrooms, kitchen and other utility spaces including lobbies are galleries for display of artworks on all available walls. 


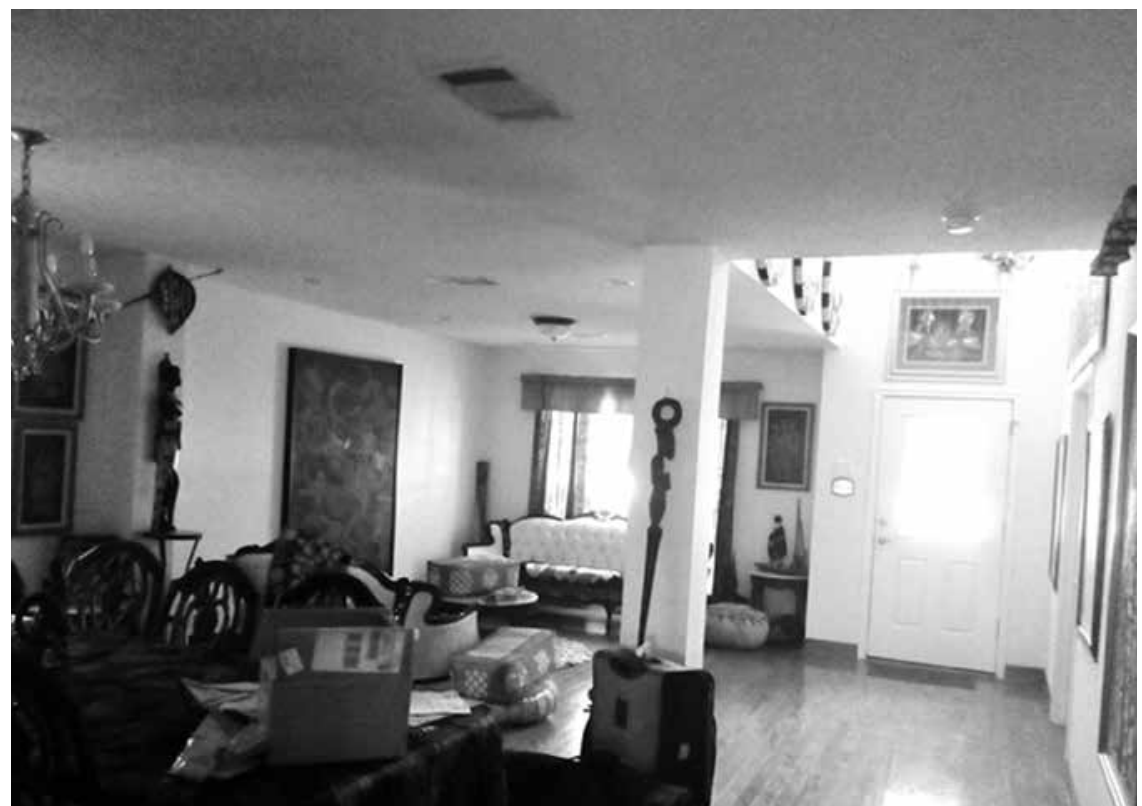

Figure 2: Interior view of the House

The double volume entrance portion leads right into a reception sitting room, and signals the first view of the impressive array of artworks, ranging from sculptures to paintings, of various sizes and shapes. The artworks are all either placed on several surfaces available or displayed on all the walls including the six-meter-high wall to the left hand of the entrance. Even the only visible column in the house has appropriately sized artworks displayed on it. The artworks are all essentially derived from Yoruba aesthetic and historical motifs, from Yoruba gods and goddesses to Yoruba cultural themes and abstracts. But there are also non-Yoruba artistic representations. On the six-meter-high wall, there is a Hausa leather mural. And one can also see some Benin bronze works on a table by the right-hand side of the column (Fig 3). The art pieces are from the old master Lamidi Fakeye, his son, down to Moses Ogunleye, and Aderonke Adesanya. And many countless others.

Off the reception living room is a study that contains more artworks, as well as the numerous awards plaques and certificates of Toyin Falola. Visibly displayed on a table is a full-size crown that represents part of the complete apparel of the Alaafin of Oyo. Immediately following this room is the guest toilet. All the toilets in the Falola house are not left out of the personalization effect (fig. 3). So also are all the bedrooms (see fig. 7) and the dining too. In all the rooms upstairs as well as the waiting area and the study, the artworks compete with the many books for aesthetic visibility. 


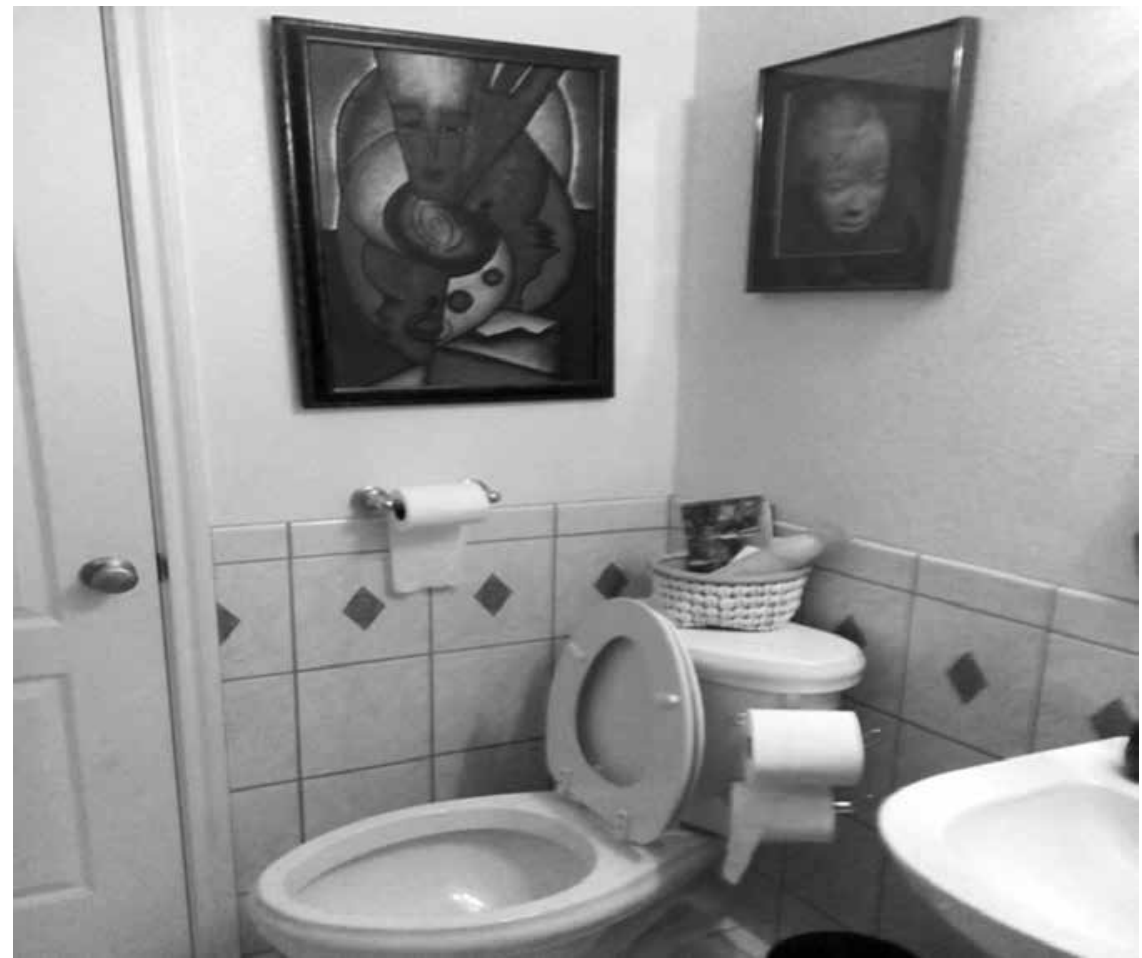

Figure 3: One of the Bathrooms in the House

From the reception sitting room, one goes straight into the double volume main living room with art works hung on the connecting wall, and on both side walls at the connecting entrance way. The double volume main living room with fireplace, the dining that is adjacent but with normal floor to ceiling height with the kitchen that opens to both and the open stairway is the main gallery of this home museum. The artworks on display on the double storey height completely dwarf the usual effect of the fireplace in temperate region living rooms (Figs. 4 and 5). 


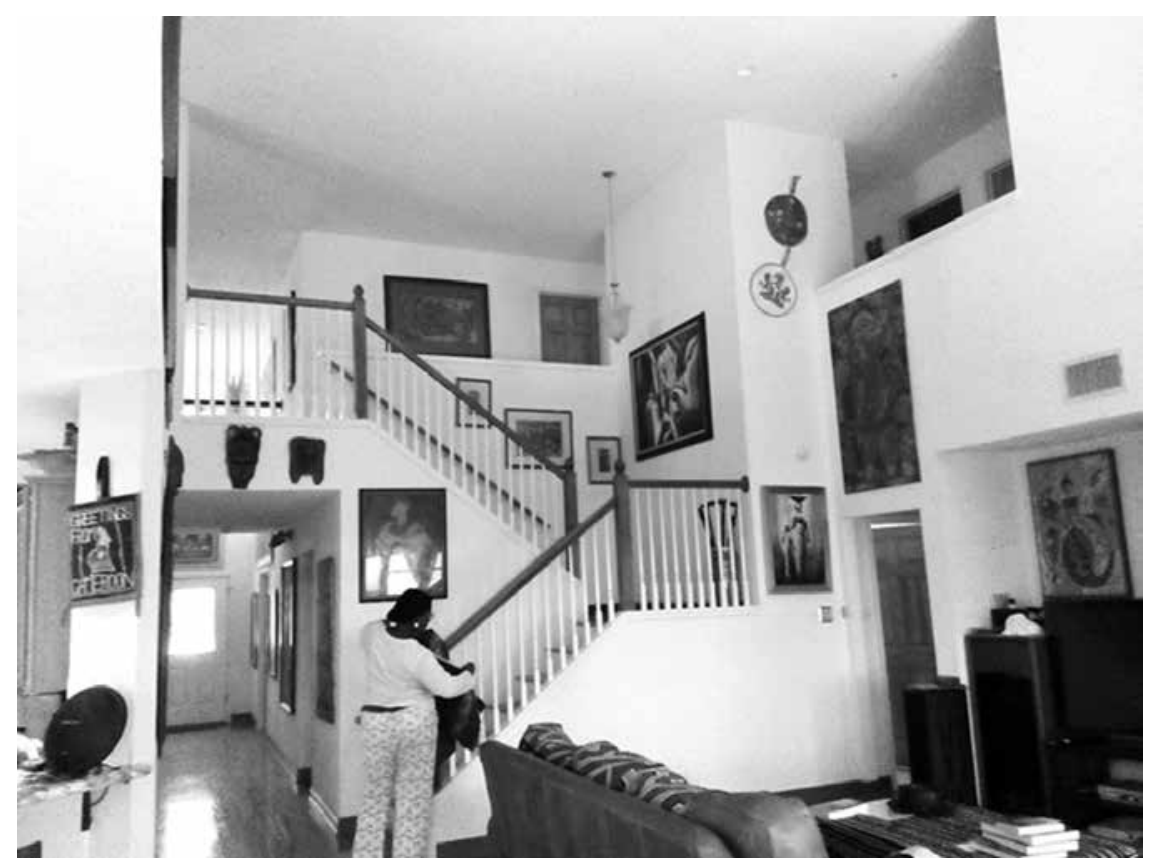

Figure 4: Artworks on the Interior Walls of the House I

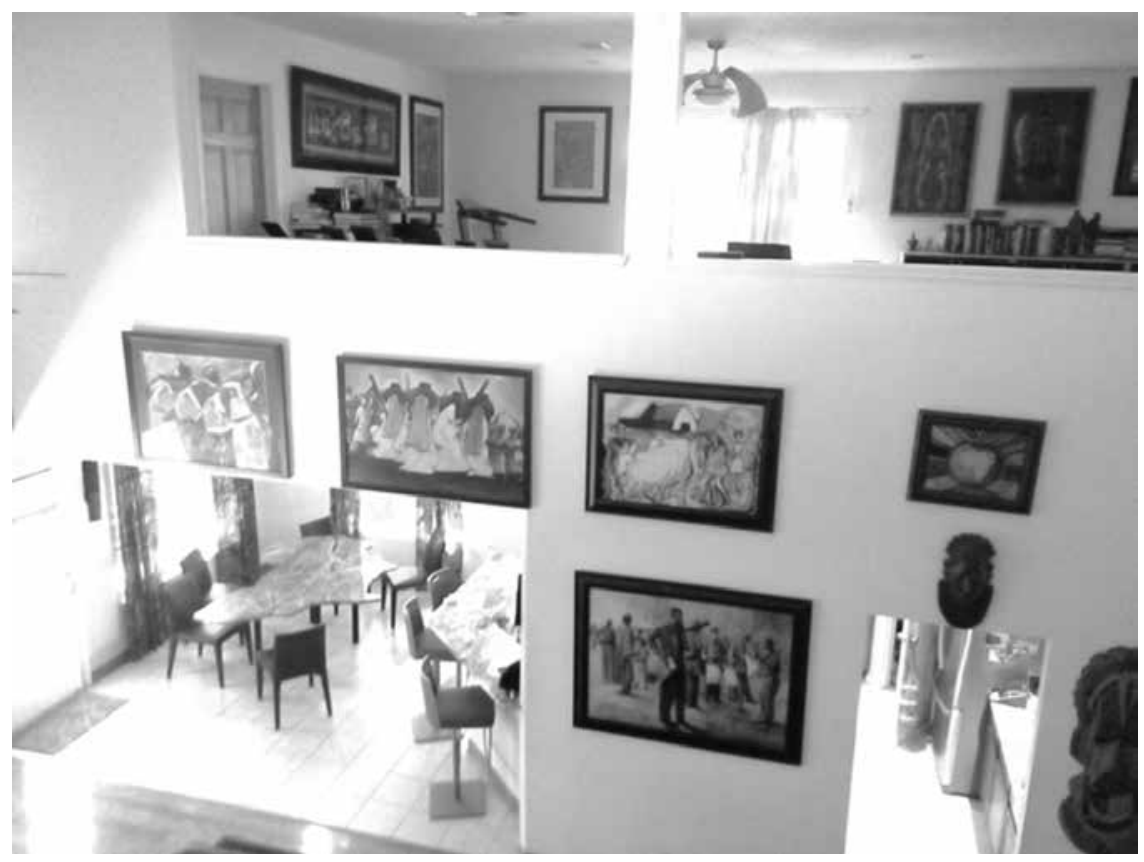

Figure 5: Artworks on the Interior Walls of the House II 
The dining table provides an outsized signifier of Toyin Falola's Afrocentric persona: it is a map of Africa, done in marble and on metal legs. The curtains in the living areas and some bedrooms, the table covers in the reception living room and wherever clothing material is needed are all done in Yoruba àdìrẹ type textile.

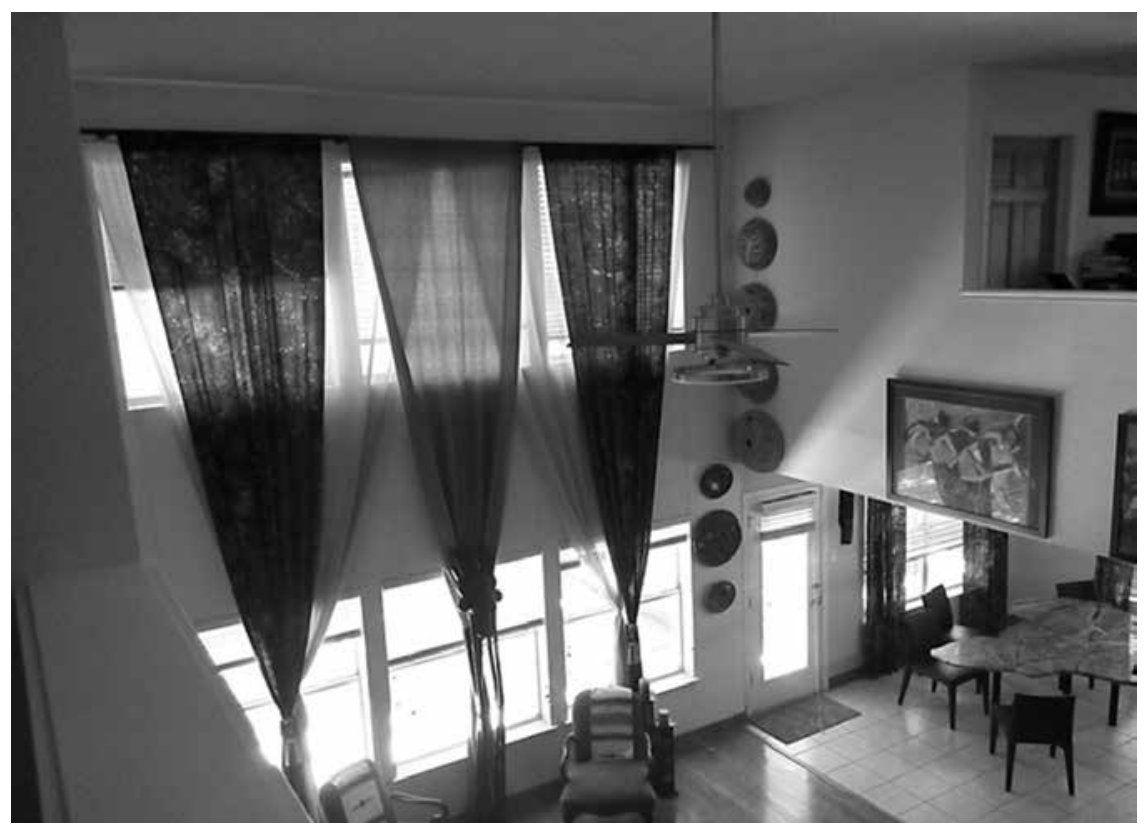

Figure 6: Artworks on the Interior Walls of the House III

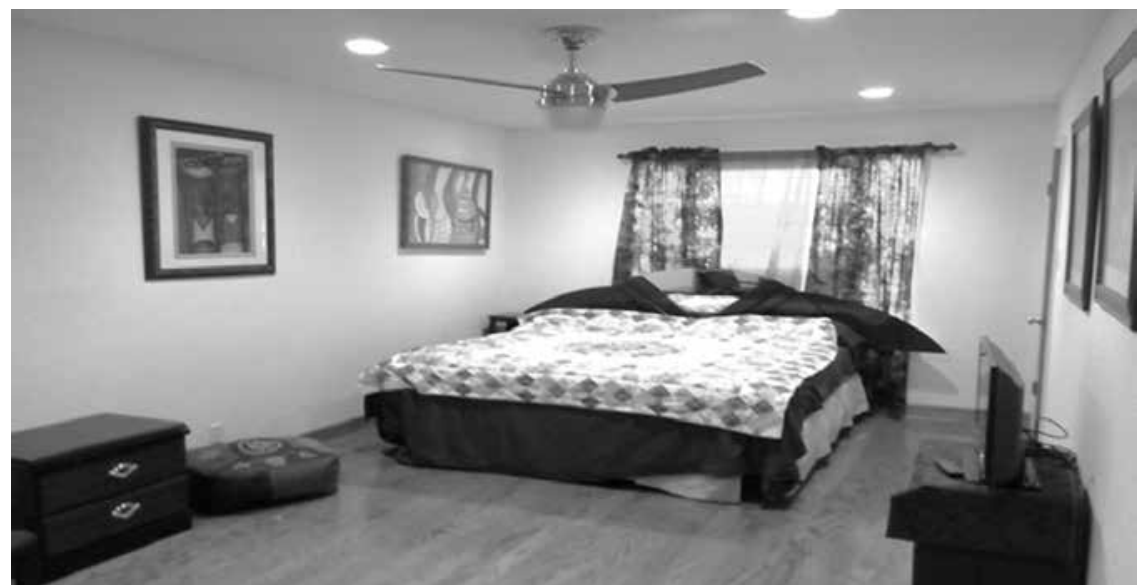

Figure 7: Artworks on the Interior Walls of one of the Bedrooms 


\section{Conclusion}

In Toyin Falola's personalized house, art and the aesthetic became a means by which home-making is transformed into an ideological means by which a transnational sense of loss and cultural dislocation are arrested and subordinated to Afrocentric dynamics. This is a consciously designed home that reflects the aesthetic choices of the owner. In a global city like Austin, Falola's house serves as a critical nod to the urgency of inscribing the local into the global. It serves as a transnational space where aesthetic sensibility of Africa disrupts the invisibility of African art on the global art scene. The Falola home at Austin instigates a discourse on Africa and Africana experience of dislocation and loss. The diaspora is a space of cultural ambiguities that mediate and modulate identity framework. If we ask the question: How do I leave the homeland and still be at home, the answer hits you in the face and the heart immediately you step into the Falola home.

\section{References}

Beck, R. M. "Aesthetics of Communication: Texts on Textiles (leso) From the East African Coast (Swahili)." Research in African Literatures. 31.4, (2000): 104-124.

Berry, J. W., \& D. Sam. “Acculturation and adaptation.” In J. W. Berry, M.H. Seagull, \& C. Kagitcibasi (Eds.), Handbook of Cross-Cultural Psychology. Boston: Allyn and Bacon, 1997.

Binsbergen, Wim van. "Globalization, consumption and development." In R. Fardon, W.M.J. van Binsbergen, and R.A. van Dijk (Eds.) Modernity on shoestring: Dimensions of globalization, consumption and development in Africa and beyond. Leiden: EIDOS:3-9

Busch, A. Entrepreneurial city: Race, the environment, and growth in Austin, Texas, 1945-2011. Unpublished Doctoral Dissertation, University of Texas at Austin, 2011.

Carlyle, E. America's 20 Fastest Growing Cities. Forbes. Available at: http:// www.forbes.

com/sites/erincarlyle/2014/02/14/americas-20fastest-growing-cities/, 2014.

Castells, M. The Rise of the Network Society. Malden, MA: Blackwell, 2000.

De Walt, P.S. "In search of an Authentic African American and/or Black Identity: Perspectives of First Generation U.S.-Born Africans Attending a Predominant White Institution." Journal of Black Studies. 42.3, (2011): 479-503.

Fidzani, L.C. \& Read, M.A. "Identity Expression and Bedroom Personalisation by Urban Adolescents in Botswana." Journal of Adolescent Research. 29.6, (2014): 691-715. 
Harney, E. et al. (Eds.). Inscribing Meaning: Writing and Graphic Systems in African Art. Milan: 5 Continents Editions, Needham Heights, MA: Allyn and Bacon, 2007.

Glick-Schiller, N., Basch, L., \& Blanc, C. S. "From Immigrant to Transmigrant. Theorizing Transnational Migration.” Anthropological Quarterly. 68, (1995): 8-63.

Glick-Schiller, N. "Transmigrants and Nations-States: Something old and Something new in the U.S. Immigrant Experience." In C. Hirschman, P. Kasinitz, \& J. De Wind (Eds.), The Handbook of International Migration: The American Experience. New York. NY: Russell Sage Foundation, 1999, pp 94-119.

Gosling, S. D., Craik, K. H., Martin, N. R., \& Pryor, M. R. "The Personal Living Space Cue Inventory: An Analysis and Evaluation." Environment and Behavior. 37, (2005): 683-705. doi:10.1177/0013916504274011

James, W. The Principles of Psychology (Vol. 1). Cambridge, UK: Harvard University Press, 1981.

Kamptner, N. L. "Treasured Possessions and their Meanings in Adolescent Males and Females." Adolescence. 30, (1995): 301-319.

Langman, L. "Culture, Identity and Hegemony: The Body in a Global Age." Current Sociology. 51.3/4, (2003): 223-247.

Long, J. "Constructing the Narrative of the Sustainability Fix: Sustainability, Social Justice and Representation in Austin, TX." Urban Studies 53.1, (2016): 149-172.

Marcus, C. C. \& W. Sarkissian. Housing as if People Mattered: Site Design Guidelines for Medium-Density Family Housing. London, England: University of California Press, 1984.

Skandrani, S.M., O. Taieb, \& M.R. Moro. “Transnational Practices, Intergenerational Relations and Identity Construction in a Migratory Context: The case of Young Women of Magrebine origin in France. Culture \& Psychology. 18.1, (2012): 76-98.

Swearingen, W.S. Environmental City: People, Place, Politics, and the Meaning of Modern Austin. Austin, TX: University of Texas Press, 2010.

US Census. "Austin, TX Link to County and City Databases." Available at: http://quick facts.census.gov/qfd/states/48/4805000.html, 2014.

Weigert, A. J., J.S. Teitge, \& D.W. Teitge. Society and Identity: Toward a Sociological Psychology. Cambridge, UK: Cambridge University Press, 1986. Wise, Macgregor. Cultural Globalization: A User's Guide. Malden, MA: Blackwell Publishing, 2008. 